\title{
Wheat Industry: Which Factors Influence Innovation?
}

\author{
Vitor Francisco Dalla Corte ${ }^{1^{*}}$, Paulo Dabdab Waquil ${ }^{2}$, Kyle Stiegert ${ }^{3}$
}

\begin{abstract}
A change in the profile of food consumption is occurring because of the new context of demographic growth, the increase of income in developing economies, and urbanization. In Brazil, consumption patterns have trended from fresh to processed food and internal and external growth in demand has led to opportunities that require new and higher levels of technological innovation and associated managerial skill. The aim of this study was to evaluate the role of innovation on a key Brazilian food industry: wheat product markets. Results showed that while most firms did not innovate in the past year, new investments in R\&D were important for innovation to occur compared to other factors such as the size of the company, the integration in supply chain, and the age of the company. These results demonstrate that innovation is not a random or unpredictable process, but a complex and diverse process that may be specific to each industry.
\end{abstract}

Keywords: innovation; food industry; wheat products.

Submitted August 26th 2015 / Approved September 30th 2015

\section{Introduction}

The profile of food consumption in many countries, both with respect to quantity and quality, is changing rapidly in response to changes in population growth, the increase in income in developing countries, and urbanization. In Brazil in particular, consumption shifted from fresh to processed food in recent decades. Currently, $85 \%$ of food is processed, a significant increase from earlier periods: 70\% in 1990 and 56\% in 1980 (ABIA, 2013). This increase corresponds with a dramatic increase $(195 \%)$ in the revenues in the food industry, which were R\$ 104.4 billion in 2002 and rose to R\$353.9 billion in 2012. While most of this growth has been driven by domestic sales, increasing external sales also provide opportunities for growth.

The food sector has traditionally been viewed as a mature low-technology industry with slow rates of innovation. However, increases in the growth of internal and external demand in processed food has stimulated new investments in developing new technologies and improved management to maintain competitiveness. In this context, Brazilian food sector innovation has become one of the main driving forces in economic development and business competitiveness. The biotechnology revolution along with competitive pressures associated with lower import protection has incentive the food sector to improve control processes, capture economies of scale, improve food safety measures and nutritional quality, and to develop a new generation of foods to supply consumers that demand greater convenience, variety and quality (Traill and Meulenberg, 2002).
The food processing industry in Brazil has been the main technological innovator in the agrifood chain. Therefore, it is important to systematically evaluate the innovation process in the industry, since it consists of a significant share of the agribusiness sector and the entire economy. In the wheat industry in particular, proper innovation can provide firms with a major competitive advantage. Many studies have been conducted with the aim of identifying the factors that influence or determine the level of innovation in the wheat industry and/or food companies (Traill and Grunert, 1997; Roeder et al., 2000; Dobson et al., 2001; Avermaete et al., 2004; Cabral, 2007; Brewin et al., 2009; Capitanio et al., 2010; Triguero et al., 2013). However, the results of these studies are often contradictory. The research in this paper indicates that while innovation is a complex and diverse process, the process is not random and unpredictable. Furthermore, there may be observable trends that are specific to a particular company or industry. Therefore, given the importance of innovation for both economic growth and business competitiveness, understanding the factors that influence or determine innovation within firms and the industry is of great importance. This understanding can help firms increase their own efficiency and allow the government to implement the appropriate policies for technological innovation.

\section{Innovation and its Determinants}

The modern food chain has become increasingly complex, which leads to new and unique challenges for researchers. In the early $20^{\text {th }}$ century, agricultural markets were comprised of a limited variety of

1 Business Graduate Program, Faculdade Meridional (IMED), Passo Fundo, RS, Brazil.

2 Center of Studies and Researches in Agribusiness (CEPAN), Federal University of Rio Grande do Sul (UFRGS), Brazil.

3 Department of Agricultural \& Applied Economics (AAE), University of Wisconsin (UW), Madison, WI, USA.

*Corresponding author: vitor.corte@imed.edu.br 
products for basic consumption, homogeneous technologies for production and processing, and consistent information for all consumers. Additionally, large agribusiness firms enjoyed high levels of market power leading to large profits. In recent decades, rapidly developing product differentiation, new production methods, and growing urban markets has led to a diversified farming and agribusiness industries with widely diversified economic outcomes.

The proposal of Schumpeter (1939) was to relate the essence of economic development to innovation. Therefore, innovation would be the heart of the economic system, serving as the main engine of capitalist development and a source of profit. The innovative businessman would be the main drivers of technological development and, consequently, they would capture extraordinary profits (Zawislak, 2004).

Firms formalized innovation internally through research and development (R\&D) departments, which institutionalized the firm's growth in process and technical efficiency (Penrose, 1959). Coase (1937), argued that a series of transactions could be arranged outside the market and regulated by the firm. This innovation would serve to lower transaction costs. His point was that the management of resource allocation would be dependent on intangible entrepreneur-coordinator assets, responsible for finding superior organizational formats that reduce transaction costs. In the context of Sumpeter and Coase, the firm is ultimately responsible for managing both tangible (technologies) and intangible (knowledge) assets by utilizing information within an institutional environment for decision making. The firm can develop new technologies or search for alternatives to their hierarchy in order to remain competitive. These technologies can lower costs of production, streamline processes, improve quality, or expand what the firm does. In an increasingly competitive, intense, and dynamic environment, the need for up to date information becomes essential for the firm. Therefore, the firm seeks knowledge about consumers and competitors. Firms gradually pass from the condition of a single period profits maximizer to problem solvers (innovative) to obtain and maintain a long-run stream of profits.

Building on the view of firms as problem solvers, the "evolutionary theory" developed by Nelson and Winter (1982) arises. The starting point of this theory is that the firm becomes the locus of technological accumulation, including not only new technologies, but also knowledge and learning. As firms innovate, their technological knowledge and managerial skill would not be easily copied because other firms cannot observe the underlying details of private changes and they could not easily access new technologies. The transfer of such knowledge would be costly and would necessarily require learning. Some technologies cannot be imitated at all. In these cases, new technologies originate from the initiative and effort of their own firms as they adapt to their particular assets and institutional environment. Therefore, the creation of a new technology requires skills, effort and investment of each firm. Dosi and Orsenigo (1988) affirms that the evolutionary theory can explain the permanent existence of asymmetries between firms, in terms of the technologies utilized and the quality of production. There are different degrees of technology accumulation and different efficiencies in technological and innovative research process. Technological change is understood as a continuing process of either the adoption of existing technologies or the creation of new technical knowledge, which is determined by the external inputs and the previous accumulation of capabilities and knowledge of the firm.

There is an ongoing debate about the nature of the innovation process. Innovation is recognized as a driving force for the economic development and competitiveness of the firm and, as a result, this increases our interest in understanding the factors that determine this process. The research presented in this paper is constructed on the internal development of new technologies and new strategies that alter the existence, functioning, behavior, and the role played by markets. Our work is consistent with studies by Cesaratto and Mangano (1993), Christensen (1996), and Cabral (2007) which define innovation as being either new to the world, country or company, thus utilizing a wider approach to measuring innovation.

Note that the Schumpeterian view of innovation would be predominantly associated with radical innovation. He does not consider cascading technical improvements of new products or processes as innovation. For Schumpeter (1934), large companies would innovate more than small firms. The study of Scherer (1992) confirms this hypothesis, demonstrating that $90 \%$ of R\&D performed in the U.S. is conducted by four major corporations. However, studies have recently found evidence that small and medium food companies invest heavily in innovation (Traill and Grunert, 1997; Avermaete, et. al., 2004).

The size of the company could potentially be related to its market power upstream or downstream, and this would influence the innovation process. Several research studies evaluate innovation in the food industry and its relation to the upstream and downstream sectors. In a study of the European retail sector, Dobson et al. (2001) show that increasing the market power of retailers can lower prices, but also reduce product variety and innovation efforts of the agri-food businesses. Studying the effect of market structure on innovation of agri-food products in the U.S., Roeder et al. (2000) state that there is a strong negative correlation between market concentration and innovation. Another study conducted by the Federal Trade Commission (FTC, 2003) also suggests a strong negative correlation between market concentration and innovation. The authors suggest that higher market dominance by a few companies lowers the propensity for innovation.

In a survey in the German food industry, Weiss and Wittkopp (2005) find that an increase in market power in the retail sector decreases innovation by manufacturers. The market power of retailers has negative effects on innovation in food manufacturing, which is measured by the number of new products introduced in the market.

Another study analyzes how downstream firms with market power force suppliers into exclusive agreements and, thus, reduce incentives to innovate (Inderst and Wey, 2006). In summary, the market power of downstream firms may reduce incentives for innovation by food manufacturers. Similar effects can be expected if there is market concentration of upstream suppliers. 
On the other hand, the research conducted by Triguero et al. (2013) find that certain factors, such as positive evolution of the market share of firms, are not strongly related to innovation in the Spanish food industry. Following the same reasoning, Bhattacharya and Bloch (2004) argue that a high market concentration can provide an opportunity for small businesses to capture a share of market power through innovation, and the intensity of R\&D would not have a positive or significant relation to innovation.

The number and size of firms (market concentration), the degree of product differentiation, and market size may all affect the number of innovations in a nonlinear manner (Roder, et. al., 2000). Therefore, it is important to include specific characteristics of each sector when analyzing the relationship between firm size and innovation.

Existing differences in the intensity and source of technological innovation and individual factors, such as firm size, may not be sufficient to predict and explain innovative activity. A linear model of innovation, characterized by a unidirectional relationship to company size, as proposed by Schumpeter (1934), may be inadequate for explaining the complex process of technological innovation.

Directly related to the Schumpeterian view of technical progress, Nelson and Winter (1982) describe the Evolutionary Theory of Economic Change, in which change is understood as technological development. The generation and application of new technologies begins with the initiative and effort of the firms. This process is described as an adaptation of the specific assets in an institutional environment. Developing specific expertise (routines or genes) and perception (based on the ability and limited rationality of their managers), firms have the technological competence to ensure their survival in competitive situations, which can be adverse.

The competence of a company is based on their internal ability to change the combination of factors (a mutation) in a specific way to seek gains in the market. Thus, the competition among different technologies (generated by different firms) in the market results in a natural selection. The very essence of technological and economic development rises from the gene-mutation-selection process (Nelson and Winter, 1982).

Dosi (1982) describes a complex structure of relations between the economic environment and the direction of technological change. A theory of technical change would define, as generally as possible, the nature of these interactive mechanisms, which can act as either a source of homogeneity or heterogeneity among industries or companies.

Although under the same technological regiments, the firms may differ in many other relevant aspects. Considering its interaction with the economic environment, firms can present business strategies (including, for example, R\&D and prices) and organizational structure (such as having different levels of vertical integration and horizontal diversification) (Dosi and Orsenigo, 1988). Consequently, innovation in the wheat industry can be related to greater vertical integration in the production chain.

In addition, innovations can be developed or generated either internally or externally to the company and can result from $R \& D$, learning from patent acquisitions, improved know-how or new equipment and machinery. However, there is an expectation that consolidated companies (longevity in market) are more prone to innovate. These companies have greater experience that facilitates cumulative learning and, consequently, can improve the innovative performance.

\section{Materials and Methods}

To obtain the necessary information for this study, an online questionnaire was developed and sent by email to the directors or product development sectors at 179 companies. Before sending the link, respondents were contacted by telephone to explain the research objectives and to describe the questionnaire.

The sample was composed by the companies registered in class associations, which are responsible for process more than $80 \%$ of national production volume of wheat products. The questionnaire was sent to 40 companies registered in ABITRIGO (Brazilian Association of Wheat Industry), 30 from ABIMA (Brazilian Association of Pasta Industry), 61 from ANIB (Brazilian Association of Biscuits) and over 48 companies registered in ABIA (Brazilian Association of Food Industry). Data was collected from October to December 2013. From 179 companies invited to participate on the study, 51 questionnaires were returned with valid responses, representing a response rate of approximately $28 \%$.

In this paper, a logistic regression is used to analyze the determinants of innovation. For this logistic regression, information on whether or not innovation occurred is needed to determine a dichotomous value ( 1 if there is innovation or 0 if there is not) as the dependent variable. From this binary outcome, the logistic regression estimates the probability that an event occurs (Gujarati, 2006).

The likelihood that firms innovate is estimated from the identification of independent variables that are hypothesized to impact the dependent variable. The logistic regression assumes a relation between the dependent and independent variables that resembles an S-shaped curve, in which at very low levels of the independent variable, the probability tends to zero, but as the independent variable increases, the probability initially increases rapidly. Then, the slope begins to decrease, so that at any level of the independent variable, the probability will tend to one, but will not exceed this value (Gujarati, 2006). Logistic regression does not require normality of the error term. This method resembles, in many respects, the multiple linear regression, however the logistic regression provides a direct prediction of the probability of an event occurring (Hair, et. al., 2008).

Estimative of logistic coefficients $(\beta 0, \beta 1, \ldots, \beta \mathrm{n})$ are used to explain the changes in probability and are expressed in logarithms, needing to 
be transformed back (antilogarithm) for analysis. For example, if $\beta 1$ is positive, the transformed antilog is greater than 1 , and the inequality ratio increases, thus increasing the predicted probability of occurrence (yes) and decreasing the likelihood of the event to not occur (no). Another difference compared to the multiple regression analysis is the method of estimating the coefficients. Instead of minimizing the squared deviations (least squares method), a logistic regression maximizes the likelihood (best estimate) of an event occurring due to non-linearity of the logistic transformation (Hair et al., 2008). To evaluate the explanatory power of the model, I calculate the Nagelkerke $\mathrm{R}^{2}$, with values from 0 to 1 (where values closer to 1 indicate higher explanatory power). To determine which independent variables are significant determinants of innovation, the Wald statistic is calculated. The hypothesis that at least one of the coefficients in the ratio of inequality influences and modifies the probability of an event occurring or not was tested (Gujarati, 2006).

A model of estimation is utilized to identify variables with explanatory power for the propensity of a firm to innovate or not, according to Equation 1:

$$
\mathrm{Y}=\beta_{0}+\beta_{1} \mathrm{X}_{1}+\beta_{2} \mathrm{X}_{2}+\beta_{3} \mathrm{X}_{3}+\beta_{4} \mathrm{X}_{4}+\beta_{5} \mathrm{X}_{5}+\beta_{6} \mathrm{X}_{6}
$$

$\mathrm{Y}=$ Innovation $(1=$ innovate, 0 otherwise $)$

$B 0=$ Constant;

$\beta 1=$ coefficient for the number of employees - FUNC4;

$\beta 2=$ coefficient for the gross sales - FATB9;

$\beta 3=$ coefficient for the investment in R\&D - INVPED11;

$\beta 4=$ coefficient for the R\&D department - SNPED6;

$\beta 5=$ coefficient for the longevity in market - ANO1;

$\beta 6=$ coefficient for the integration in the production chain - NPROD2;

$\mathrm{X} 1$ = number of employees - FUNC4

$\mathrm{X} 2$ = gross sales - FATB9;

$\mathrm{X} 3$ = investment in R\&D - INVPED11;

$\mathrm{X} 4=\mathrm{R} \& \mathrm{D}$ department - SNPED6;

$\mathrm{X} 5$ = longevity in market - ANO1;

$\mathrm{X} 6$ = integration in the production chain - NPROD2

As discussed above, the size of the company can be one of the factors that increases the propensity of the firm to innovate, therefore the variables of the number of employees (FUNC4) and gross sales (FATB9) are considered. Another factor potentially related to the propensity to innovate is research and development. It is assumed that firms with higher investments in R\&D (INVPED11) and having a formalized department of R\&D (SNPED6) are more likely to innovate. We also considered the age of the company (ANO1), expecting that cumulative learning increases the propensity to innovate. Finally, the production chain (NPROD2) is also included, with the assumption that a higher level of integration increases the propensity to innovate.

In addition, to estimate the probability of an event to occur, a logit transformation is needed according to

Equation 2 (Gujarati, 2006):

$$
P i=\frac{1}{1+e^{-(\beta 0+\beta 1 \mathrm{X} 1+\cdots+\beta \mathrm{nXn})}}=\frac{\exp (\beta 0+\beta 1 \mathrm{X} 1+\cdots+\beta \mathrm{nXn})}{1+\exp (\beta 0+\beta 1 \mathrm{X} 1+\cdots+\beta \mathrm{nXn})}
$$

$\mathrm{Pi}=$ exponential of event occurring;

$e^{-(\beta 0+\beta 1 X 1+\ldots+\beta n X n)}=$ exponential of the negative logistic equation.

The logit function also allows simulations of how the probability of innovating changes in a company, changing the independent variables, which will be presented in the following results.

\section{Results and Discussion}

As described in materials and methods section, 51 valid responses were received. 28 firms did not innovate (55\% of the 51 responses) and 23 (45\%) of the responses indicated an innovation occurred in the recent period (last five years). These findings suggest that most companies producing wheat products innovated more rapidly compared to the innovation in the Brazilian food industry in general but lower than in other regions. Rates of Brazilian food industry innovation reported in Innovation research - PINTEC (2000; 2003; 2005; 2008) suggest an increasing trend: 1998-2000: 29\%; 2001-2003: 34\%; 2003-2005: 32\%; 2006-2008: 38\%. In the European Union this percentage is above 55\%, according to data from the Community Innovation Survey (CIS, 2013).

Based on these results, and in the context of an increasingly competitive environment and complex consumer profiles, there is a growing opportunity for more companies to innovate. As described above, a logistic model is utilized to identify variables that influence the propensity of firms to innovate. The variables are mainly related to firm size, research and development, the age of the company, and integration in the supply chain. The results are shown in Table 1. 


\begin{tabular}{|c|c|c|c|c|c|c|}
\hline Determinant & Variable & Code & Coefficient & Wald & $\mathbf{p}$ & $\operatorname{Exp}(\beta)$ \\
\hline & Constant & & -3.912 & 5.500 & $0.019^{*}$ & 0.020 \\
\hline \multirow{2}{*}{ Size } & Number of employees & FUNC4 & 0.006 & 2.373 & 0.123 & 1.006 \\
\hline & Gross sales & FATB9 & 0.274 & 0.529 & 0.467 & 1.315 \\
\hline \multirow{2}{*}{ R\&D } & Investments $\mathrm{R} \& \mathrm{D}$ & INVPED11 & 1.749 & 4.453 & $0.035^{\star}$ & 5.748 \\
\hline & Department of R\&D & SNPED6 & 1.383 & 0.750 & 0.464 & 1.308 \\
\hline Longevity & Age of the company & ANO1 & 0.021 & 1.030 & 0.310 & 1.021 \\
\hline \multirow[t]{4}{*}{ Integration } & Integration in the production chain & NPROD2 & -0.737 & 0.865 & 0.352 & 0.479 \\
\hline & $\chi^{2}$ & & 28.377 & & 0.000 & \\
\hline & $\mathrm{R}^{2}$ Nagelkerke & & 0.671 & & & \\
\hline & $\mathrm{n}$ & & 51 & & & \\
\hline
\end{tabular}

Table 1. Logistic Regression Results

Note: ${ }^{*}$ Significant $(p<0.05)$

The chi-square $\left(\chi^{2}\right)$ statistic tests the joint hypothesis that all the independent variables do not explain innovation. The null hypothesis is soundly rejected which indicates the model is explaining innovation. The goodness of fit measure of the model (Nagelkerke $R^{2}$ ) is quite high for a logistics regression (0.671) in which innovation versus no innovation are centered on single integer outcomes of 1 or 0 . This indicates the model is performing very well.

For the proposed model, investment in research and development is found to significantly influence the likelihood of innovation, with a coefficient of 1.749 for the Wald test and indicated by the value of the lower level of significance ( $\mathrm{p}<0.05)$. A practical interpretation of the slope of coefficients estimated by the logistic regression was required. Therefore, the exponential $\operatorname{Exp}(\beta)$ is calculated using statistical odds ratio (Table 1). This shows that an increase in $R \& D$ increases the probability of innovation by 5.748 times. To understand this further, the probability of innovation is estimated by the logit transformation, considering different percentages of the company annual gross revenues invested in R\&D. Figure 1 displays this result.

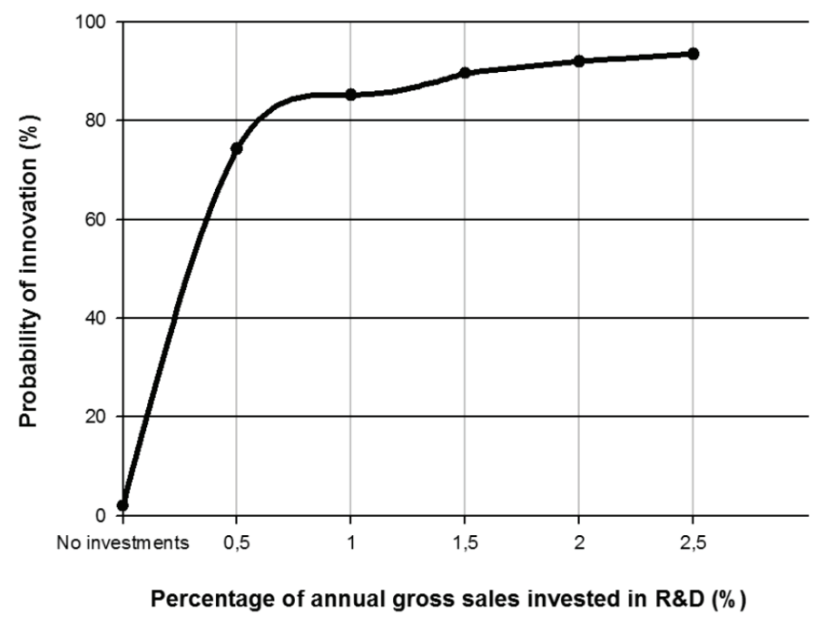

Figure 1. Probability of innovation in different percentages of investments in R\&D
It can be observed that the likelihood of the company to innovate increases as the investments in R\&D grows, particularly at low levels of investment. Even when the investments are relatively low $(0.5 \%$ of gross revenues), they can increase the likelihood that a company innovates from $1.96 \%$ to $74.32 \%$, reinforcing the importance of investment in $R \& D$ to innovate.

From the estimation of the logistic regression, variables such as the performance in the supply chain (NPROD2), the number of employees (FUNC4), the gross revenues of the company (FATB9), and the time of the company on market (ANO1) are not significantly related to the propensity of firms to innovate.

This result confirms, in part, the findings reported in literature, in which R\&D determines the propensity of firms to innovate, but the size of the company, its experience (time in the market), and the integration in the supply chain may not be significantly related to the propensity to innovate.

\section{Conclusion}

The study investigated the innovation in the industry of wheat products in Brazil. The study shows that most companies (55\%) did not develop or implement innovations.

It is found that investment in research and development significantly increases the likelihood that a company innovates. Variables related to firm size and time in the market could be significantly related to the propensity to innovate was not confirmed. Therefore, even relatively smaller and newer companies have the potential to innovate, especially when investing in $\mathrm{R} \& \mathrm{D}$. Therefore, investing in $\mathrm{R} \& \mathrm{D}$ can be a way for companies to start their innovation processes.

Considering the importance of innovation for both firms and the broader economy, the study provides important information about the factors that influence or determine the innovative activity of enterprises, associations and developers classes of policies. The results 
show that this is not a random or unpredictable process, but something complex and diverse that can be specific to each industry.

There are a number of opportunities for the processing industry to be more innovative, which can benefit all segments of the production chain, from the production of wheat processing industry to, therefore, benefit consumers and conquer new markets. Although all limitations for smaller companies to innovate, innovative behavior will be required to ensure competitiveness in the new competitive environment with new consumption patterns. Investments in R\&D may still be a great advantage for innovation.

\section{Acknowledgements}

Conselho Nacional de Desenvolvimento Científico e Tecnológico- CNPq, Coordenação de Aperfeiçoamento de Pessoal de Nível Superior - Capes.

\section{References}

ABIA. Associação Brasileira das Indústrias de Alimentação (2013). Retrieved from http://abia.org.br/vst/o_setor_em_numeros.html

ABIMA. Associação Brasileira das Indústrias de Massas (2013). Retrieved from http://www.abima.com.br/.est_mmundial.html

ABITRIGO. Associação Brasileira da Indústria de Trigo (2013). Retrieved from http://www.abitrigo.com.br/index.php?mpg=09.00.00

ANIB. Associação Brasileira da Indústria de Biscoitos (2013). Retrieved from http://www.anib.com.br/dados_estatisticos

Avermaete, T., Viane, J., Morgan, E., Pitts, E., Crawford, N., \& Mahon, D. (2004). Determinants of product and process innovation in small food manufacturing firms. Trends in Food Science \& Technology, 15(10), 474-483.

Bhattacharya, M., \& Bloch, H. (2004). Determinants of innovation. Small Business Economics, 22(2), 155-162.

Brewin, D., Monchuk, D., \& Partridge, M. (2009). Examining the adoption of product and process innovations in the canadian food processing industry. Canadian Journal of Agricultural Economics, 57(1), 75-97.

Cabral, J. (2007). Determinantes da propensão para inovar e da intensidade inovativa em empresas da indústria de alimentos do Brasil. Revista de Administração Contemporânea, 11(4), 87-108.

Capitanio, F., Coppola, A., \& Pascucci, S. (2010). Product and process innovation in the italian food industry. Agribusiness, 26(4), 503-518.

Cesaratto, S., \& Mangano, S. (1993). Technological profiles and economic performance in the Italian manufacturing sector. Economics of Innovation and New Technology, 2(3), 237-256.
Christensen, J. (1996). Innovative assets and inter-asset linkages: a resource-based approach to innovation. Economics of Innovation and New Technology, 4(3), 193-209.

CIS. Community Innovation Survey (2013). Retrieved from http://epp. eurostat.ec.europa.eu/portal/page/portal/microdata/cis

Coase, R. (1937). The Nature of the Firm. Economica, 4(16), 386-405.

Dobson, P., Clarke, R., Davies, S., \& Waterson, M. (2001). Buyer power and its impact on competition in the food retail distribution sector of the European Union. Journal of Industry, Competition and Trade, 1(3), 274-281.

Dosi, G. (1982). Technological trajectories and technological paradigms. Research Policy, 11(3), 147-162.

Dosi, G., \& Orsenigo, L. (1988). Industrial Structure and Technical Change in Innovation, Technology and Finance. Oxford: Basil Blackwell.

Federal Trade Commission. (2003). To Promote Innovation: the Proper Balance of Competition and Patent Law and Policy. FTC: Federal Trade Commission, USA.

Gujarati, D. (2006). Econometria básica. Rio de Janeiro: Elsiever.

Hair, J., Anderson, R., Tatham, R., \& Black, W. (2008). Análise multivariada de dados. São Paulo: Bookman.

Inderst, R., \& Wey, C. (2006). Buyer power and supplier incentives. European Economic Review, 51(3), 647-667.

Nelson, R., \& Winter, S. (1982). An Evolutionary Theory of Economic Change. Cambridge: The Belknap Press of Harvard University Press.

Penrose, E. (1959). The Theory of the Growth of the Firm. New York: Oxford University Press.

PINTEC. Pesquisa de Inovação (2000). Retrieved from http://www. pintec.ibge.gov.br/downloads/PUBLICACAO/Publicacao\%20PINTEC\%202000.pdf

PINTEC. Pesquisa de Inovação (2003). Retrieved from http://www. pintec.ibge.gov.br/downloads/PUBLICACAO/Publicacao\%20PINTEC\%202003.pdf

PINTEC. Pesquisa de Inovação (2005). Retrieved from http://www. pintec.ibge.gov.br/downloads/PUBLICACAO/Publicacao\%20PINTEC\%202005.pdf

PINTEC. Pesquisa de Inovação (2008). Retrieved from http://www. pintec.ibge.gov.br/downloads/PUBLICACAO/Publicacao\%20PINTEC\%202008.pdf 
Roeder, C., Herrman, R., \& Connor, J. (2000). Determinants of new product introductions in the US food industry: a panel-model approach. Applied Economics Letters, 7(11), 743-748.

Scherer, F.M. (1992). Schumpeter and plausible capitalism. Journal of Economic Literature, 30(3), 1416-1433.

Schumpeter, J.A. (1934). The Theory of Economic Development. Cambridge: Harvard University Press.

Schumpeter, J. A. (1939). Business Cycles: A Theoretical, Historical, and Statistical Analysis of the Capitalist Process. Philadelphia: Porcupine Press.

Traill, B., \& Grunert, K. (1997). Product and Process Innovation in the Food Industry. Suffolk: Chapman \& Hall.
Traill, B., \& Meulenberg, M. (2002). Innovation in the Food Industry. Agribusiness, 18(1), 1-21.

Triguero, A., Córcoles, D., \& Cuerva, M. C. (2013). Differences in innovation between food and manufacturing firms: An analysis of persistence. Agribusiness, 29(3), 273-292.

Weiss, H.R., \& Wittkopp, A. (2005). Retailer concentration and product innovation in food manufacturing. European Review of Agricultural Economics, 32(2), 219-244.

Zawislak, P. A. (2004). Economia das Organizações e a Base para o Pensamento Estratégico. In: S. Clegg; C. Hardy; W. Nord; M. Caldas; R. Fachin \& T. Fischer. (Eds.), Handbook de Estudos Organizacionais: Ação e Análise Organizacionais (pp. 180-185). São Paulo: Atlas. 